Volume 3 No 2 Maret 2018

p-ISSN : 2460-8750 e-ISSN : 2615-1731

http://dx.doi.org/10.26858/talenta.v3i2.5562

\title{
HUBUNGAN DUKUNGAN PARA ANGGOTA KOMUNITAS DENGAN RESILIENSI IBU DOWN SYNDROME
}

\author{
${ }^{1}$ Siti Nur Badriatuzzahroh, ${ }^{2}$ Endang Supraptiningsih, ${ }^{3}$ Stephani Raihana Hamdan \\ Fakultas Psikologi, Universitas Islam Bandung, 40116 Indonesia \\ email: 1 sitijahroh94@gmail.com, ${ }^{2}$ endang.doddy@gmail.com, ${ }^{3}$ stephanie.raihana@ gmail.com
}

\begin{abstract}
Abstrack. Researchers found a link between members community support with maternal resilience. Mother who has Down syndrome children in POTADS Bandung is able to show resilience in the face of a stressful situation in the process of raising a child's down syndrome due to the help of the community POTADS. The purpose of this study is to obtain empirical data on the corelation between community members' support and maternal resilience in mothers with Down syndrome children in POTADS Bandung. The method used is correlational. The study involved 50 mothers. The measuring instrument used is a questionnaire developed from the concept Social support from Sarafino \& Smith (2011) and Resilience Bernard (2004). The result of data processing shows the value of $r_{s}=0,322$ with $\rho=0,023$, with aspect of information support that is equal to $r_{s}=0,331$, so it can be concluded that there is positive correlation with low degree of correlation between support of community member with resilience at mother having child down syndrome in POTADS Bandung and the most supportive aspects are the information support that can increased the mother resilience.
\end{abstract}

Keywords: Community Support, Mother Resilience, Down Syndrome Children, Parents.

Abstrak. Peneliti menemukan adanya keterkaitan antara dukungan para anggota komunitas POTADS dengan resiliensi ibu. Ibu yang memiliki anak down syndrome di POTADS Bandung ini mampu bertahan dalam menghadapi situasi yang menekan dalam proses membesarkan anak down syndrome dikarenakan adanya bantuan dari komunitas POTADS. Tujuan penelitian ini adalah memperoleh data empirik mengenai keeratan hubungan antara dukungan para anggota komunitas dengan resiliensi pada ibu yang memiliki anak down syndrome di POTADS Bandung. Metode yang digunakan adalah korelasional. Penelitian ini melibatkan 50 ibu. Alat ukur yang digunakan berupa kuesioner yang dikembangkan dari konsep Sarafino \& Smith (2011) dan Bernard (2004). Hasil dari pengolahan data menunjukkan nilai $r_{s}=0,322$ dengan $\rho=0,023$, dengan aspek dukungan informasi yaitu sebesar $r_{s}=0,331$,sehingga dapat disimpulkan bahwa terdapat hubungan positif dengan derajat korelasi yang rendah antara dukungan para anggota komunitas dengan resiliensi pada ibu yang memiliki anak down syndrome di POTADS Bandung dan aspek dukungan yang paling tinggi keeratannya yaitu aspek dukungan informasi yang dapat meningkatkan resiliensi ibu.

Kata Kunci: Dukungan Komunitas, Resiliensi Ibu, Down Syndrome Anak, Orang Tua 


\section{PENDAHULUAN}

Down syndrome merupakan suatu kelainan kromosom yang pada umumnya terjadi karena adanya kromosom tambahan pada kromosom ke 21 (Papalia, Olds, \& Feldman, 2009). Perkembangan anak penyandang down syndrome memiliki perkembangan yang jauh lebih lambat dibandingkan dengan anak normal pada umumnya, sehingga diperlukan suatu terapi untuk meningkatkan kemandirian anak down syndrome. Kondisi anak down syndrome dapat bervariasi mulai dari gangguan mengunyah, menelan dan bicara, keterlambatan pertumbuhan gigi dan bahkan dapat menyebabkan gangguan kerusakan pada sistem organ seperti pengaruh kelainan kromosom dapat menimbulkan penyakit jantung bawaan pada bayi yang baru lahir (Selikowiz, 2001). Menurut Barnett dan Boyce (1995) secara fisiologis, orang tua terutama ibu harus menghabiskan sebagian besar dari waktu, energi, dan kesabarannya dalam merawat anak down syndrome.

Di Kabupaten Bandung, terdapat Komunitas yang bernama Persatuan Orang Tua Anak dengan Down syndrome atau di singkat POTADS hadir untuk membantu para orang tua dalam menerima kehadiran anak down syndrome dengan memudahkan para orang tua mendapatkan pengetahuan mengenai bagaimana membesarkan anak down syndrome.
Hasil wawancara terhadap $10 \mathrm{ibu}$ di POTADS Bandung yang mendapatkan data bahwa ibu mengalami stres serta tekanan setelah mengetahui anaknya mengalami down syndrome. Ibu menyalahkan dirinya sendiri sebagai penyebab anaknya terkena down syndrome. Begitu banyak hal yang dipikirkan ibu seperti bagaimana menjalani kehidupannya membesarkan anak down syndrome, selain itu ibu juga memikirkan bagaimana respon keluarga dan lingkungan mengenai anaknya dan ibu juga memikirkan masalah biaya terapi anak yang cukup memerlukan biaya yang tidak sedikit. Halhal tersebut membuat ibu-ibu POTADS sempat tertekan dengan perannya sebagai seorang ibu yang merasa memiliki tanggung jawab untuk merawat anak dengan baik. Perlahan-lahan dengan dibantu orang-orang terdekat di komunitas POTADS, ibu mulai terbuka mengenai kondisi anaknya sehingga mampu membangun relasi yang baik dengan para anggota komunitas maupun orang lain. Ibu juga mampu berpikir positif mengenai masa depan anaknya setelah mengikuti seminar mengenai anak down syndrome. Ibu semakin percaya dengan kemampuannya dalam merawat anak dengan mencoba rutin membawa anak terapi.

$$
\text { Terdapat faktor yang dapat }
$$
membantu Ibu dapat bertahan dalam situasi stres dan penuh tekanan. Salah satu 
faktornya yaitu dukungan sosial dari komunitas POTADS. Dari 10 ibu memaknakan dirinya mendapatkan dukungan dari para anggota POTADS dan 8 ibu terindikasikan memiliki resiliensi tinggi, namun 2 diantaranya terindikasi memiliki resiliensi rendah. Berdasarkan wawancara yang dilakukan, Ibu mendukung dan menyambut positif para anggota POTADS karena merasa terbantu dengan adanya kesehatan gratis disetiap acara yang diadakan oleh POTADS, diperhatikan, disemangati, diberi saran, masukan, serta merasa nyaman ketika berkumpul dengan para anggota POTADS yang menjadikan ibu dapat bertahan menghadapi kesulitan dalam proses membesarkan dan mendidik anak down syndrome.

Sarafino (2011, dalam Fitri), mendefinisikan dukungan sosial adalah kenyamanan, perhatian, penghargaan, maupun bantuan dalam bentuk lainnya yang diterima individu dari orang lain ataupun kelompok. Dukungan bisa didapat dari berbagai sumber daya yang berbeda, misalnya dari suami atau istri, orang lain yang dicintai, seperti keluarga, teman, rekan kerja, atau organisasi masyarakat. Ada 5 aspek dukungan sosial, yaitu: (1) Emotional or esteem support menyangkut ungkapan empati, kepedulian dan perhatian, penghargaan positif terhadap orang-orang yang bersangkutan. Dukungan menghadirkan perasaan nyaman, tentram, rasa dimiliki, dan merasa dicintai ketika mengalami stress, memberikan bantuan dalam bentuk semangat, kehangatan personal, dan cinta. (2) Tangible or instrumental support mencakup pemberian bantuan secara langsung dan nyata yang menunjukkan ketersediaan sarana untuk memudahkan perilaku menolong bagi individu yang menghadapi masalah dalam bentuk materi dan berupa jasa atau bantuan moril. (3) Informational support, dukungan dalam bentuk informasi, seperti memberikan nasihat, arahan, saran-saran, atau penilaian tentang bagaimana individu melakukan sesuatu. Misalnya individu mendapatkan informasi dari dokter tentang bagaimana mencegah penyakitnya kambuh lagi. Dukungan ini berupa informasi untuk menambah pengetahuan individu dalam mencari jalan keluar atau memecahkan masalah seperti nasehat atau pengarahan. Orang-orang yang berada disekitar individu akan memberikan dukungan informasi dengan cara menyarankan beberapa pilihan tindakan yang dapat dilakukan dalam mengatasi masalah yang membuatnya stres.

(4) Companionship support mengacu pada kesediaan orang lain untuk menghabiskan waktu dengan orang tersebut, sehingga memberikan perasaan keberadaannya dalam kelompok baik dalam berbagi minat yang sama atau kegiatan sosial.

Bernard (2004) mendefinisikan resiliensi sebagai kemampuan individu 
untuk dapat beradaptasi dengan baik walaupun ditengah situasi yang menekan atau banyak halangan dan rintangan. Resiliensi mengubah individu menjadi survivor dan berkembang. Individu yang resilien dapat mengalami penderitaan, tetapi mereka mampu mengatur perilaku yang keluarnya (outcomes) negatif dalam menghadapi halangan tanpa menjadi lemah. Resiliensi memiliki 4 aspek, yaitu: (1) Social Competence mencakup karakteristik, kemampuan, dan sikap yang diperlukan oleh individu untuk membangun suatu relasi dan kedekatan yang positif dengan orang lain. Social Competence meliputi empat sub aspek yaitu, Responsiveness, Communication, Empathy and Caring, Compassion, Altruism, and Forgiveness. (2) Problem Solving merupakan kemampuan individu untuk dapat membuat rencana dan tindakan yang akan dilakukan saat menghadapi masalah, dapat berpikir fleksibel untuk mencari solusi alternatif terhadap suatu masalah, dapat berpikir kritis dan analitis dalam mengerti suatu kejadian atau situasi. Problem solving meliputi empat sub aspek yaitu, Planning, Fexibility, Resourcefulness, and Critical Thinking and Insight. (3) Autonomy adalah kemampuan individu untuk bertindak dengan bebas dan kemampuan untuk dapat kontrol terhadap lingkungannya. Autonomy meliputi enam sub aspek yaitu, Positive Identity, Internal Locus of Control and Initiative, Self-Efficacy and Mastery, Adaptive Distancing and Resistance, Self Awareness and Mindfulness, and Humor. (4) Sense of Purpose and Bright Future adalah kekuatan untuk mengarahkan tujuan secara optimis dan kreatif untuk mengerti dan berkaitan dengan kepercayaan yang mendalam tentang arti hidup dan keberadaan dirinya.

Sense of Purpose and Bright Future meliputi empat sub aspek yaitu, Goal Direction, Achievement Motivation, and Educational Aspirations, Special Interest, Creativity, and Imagination, Optimism and Hope, Faith, Spirituality, and Sense of meaning. Salah satu faktor yang dapat meningkatkan resiliensi adalah community protective factors.

Berdasarkan latar belakang yang telah di uraikan di atas, maka rumusan masalah dalam penelitian ini "Seberapa erat hubungan antara dukungan para anggota komunitas dengan resiliensi pada ibu yang bergabung di persatuan orang tua yang memiliki anak down syndrome (POTADS) Bandung?”. Tujuan dari penelitian ini adalah untuk memperoleh data empiris mengenai keeratan hubungan antara dukungan para anggota komunitas dengan resiliensi ibu yang bergabung di Persatuan Orang Tua Anak Dengan Down Syndrome (POTADS) Bandung. 


\section{METODE}

Metode yang digunakan dalam penelitian ini adalah korelasional, yaitu untuk mengetahui tingkat hubungan antara dua variabel atau lebih tanpa melakukan perubahan, tambahan, atau manipulasi terhadap data yang memang sudah ada (Arikunto, 2010).

\section{HASIL DAN PEMBAHASAN}

Hasil

Cobb (Sarafino, 2011) menjelaskan bahwa adanya dukungan dari lingkungan seperti komunitas akan membuat kesulitan terasa lebih mudah bagi individu. Individu akan memaknai stres yang berat bukan sebagai stres yang berat. Penelitian ini telah mendapatkan hasil mengenai hubungan antara dukungan komunitas dengan resiliensi ibu yang bergabung di POTADS Bandung. Dari 50 ibu terdapat 30 orang atau $60 \%$ ibu yang memiliki anak down syndrome di POTADS Bandung memiliki resiliensi yang tinggi, artinya ibu menunjukkan perilaku yang mengindikasikan adanya peningkatan kualitas diri dan dapat menyesuaikan diri dengan berbagai rintangan yang dihadapi selama merawat anak down syndrome.

$$
\text { Tingginya resiliensi ibu }
$$
berhubungan dengan adanya dukungan dari komunitas POTADS berupa emotional or esteem support, tangible or instrumental support, informational support dan companionship support yang ibu dapatkan dari para anggota komunitas POTADS. Koefisien korelasi antara dukungan komunitas POTADS dengan resiliensi dalam penelitian ini sebesar 0.322 yang artinya dukungan komunitas POTADS dengan resiliensi pada ibu yang memiliki anak down syndrome di POTADS Bandung ini memiliki hubungan yang positif dan rendah. Maka semakin positif dukungan para anggota komunitas POTADS, maka semakin tinggi pula resiliensi ibu, begitupun sebaliknya, semakin negatif dukungan para anggota komunitas POTADS, maka semakin rendah pula resiliensi yang dimiliki ibu.

\section{Pembahasan}

Sejalan dengan konsep yang dikemukakan Sarafino \& Smith (2011), dukungan sosial bekerja dengan cara mempengaruhi proses penilaian kognitif. Ketika ibu menghadapi stressor yang kuat, maka ibu yang memiliki tingkat dukungan sosial yang tinggi akan menganggap situasi yang dihadapinya sebagai situasi yang tidak menekan. Ibu yang memiliki dukungan sosial yang tinggi dapat mengharapkan dukungan dari seseorang yang dikenalnya untuk menolong dirinya. Selanjutya, dukungan sosial menyebabkan ibu memodifikasi responnya terhadap stressor setelah mereka menilai bahwa situasi yang 
mereka hadapi adalah situasi yang penuh stres.

Ibu yang memaknakan positif dukungan para anggota komunitas akan merasa memiliki seseorang yang dapat memberikan solusi, meyakinkannya bahwa masalah yang dihadapi bukanlah sesuatu yang sangat berat dan memberi semangat untuk melihat "sisi baik" atau melihat "keuntungan yang dimiliki". Ibu yang memaknakan positif dukungan sosial menunjukkan bahwa ia mendapat pengungkapan empati dan penghargaan melalui perhatian serta pengungkapan dukungan dan dorongan untuk ibu ketika ibu mengalami permasalahan dalam mengasuh dan merawat anak. Ibu juga mendapat bantuan berupa materi dan jasa. Selain itu, ibu juga mendapat nasehat, saran, arahan, dan masukan yang bertujuan untuk memudahkan ibu dalam merawat dan mengasuh anak down syndrome. Di samping itu, terdapat pula pengurus POTADS yang bersedia untuk menghabiskan waktu bersama ibu untuk saling berkomunikasi.

Penelitian ini menunjukkan bahwa ibu yang memaknakan positif dukungan para anggota komunitas cenderung memiliki resiliensi yang tinggi pula. Hal ini sejalan dengan teori Benard (2004) bahwa ada tiga hal yang dapat diberikan lingkungan untuk meningkatkan resiliensi seseorang yaitu caring relationship, high expectation massages, opportunities for participation and contribution. Tiga hal tersebut dinamakan protective factors yang dapat ditemukan di dalam lingkungan dimana individu tinggal yang salah satunya adalah komunitas.

Aspek koefisien korelasi yang paling besar diantara keeratan hubungan yang rendah yaitu aspek informational support dengan resiliensi ibu. Hasil korelasi hubungan antara aspek informational support dengan resiliensi ibu dengan anak down syndrome yaitu sebesar 0,331 yang artinya bahwa semakin positif informational support, maka semakin tinggi resiliensi ibu. Ini dapat diartikan bahwa aspek informational support memiliki kontribusi yang lebih besar pada resiliensi jika dibandingkan dengan aspek dukungan para anggota komunitas lainnya.

Dukungan informational support yang meliputi, mekanisme penyediaan informasi, pemberian saran, nasihat, arahan, dan masukkan menjadi begitu penting karena sangat membantu ibu dalam pengambilan keputusan. Ketika ibu memaknakan positif dengan bantuan para anggota POTADS. Ibu menjadi lebih mampu menyelesaikan masalah dengan merencanakan suatu tindakan terhadap masalah anak, ibu menilai dirinya mampu menghadapi berbagai masalah mengenai anak, mampu membentuk hubungan yang hangat dengan orang lain, memiliki kemandirian terhadap tekanan sosial, 
mampu mengontrol lingkungan eksternal, serta mampu mengembangkan minat atau hobi dirinya secara berkelanjutan.

Hasil penelitian Shinta (1995) ditemukan bahwa dukungan informasi merupakan dukungan yang paling berpengaruh terhadap coping terpusat dalam penyelesaian masalah. Dukungan informasi dapat membantu ibu untuk merubah situasi yang dihadapi dan merubah pemahaman dan penilaian dari sebuah situasi. Everall, dkk (Lestari,2006) menjelaskan bahwa dengan coping terpusat masalah individu tidak menghindari dari permasalahan. Ibu akan berupaya menghadapi permasalahan tersebut, merencanakan dan mengembangkan solusi secara kreatif, serta mencari bantuan dari orang lain. Tayron (2000, dalam Lestari) mempertegas bahwa terdapat hubungan yang kuat antara coping terpusat masalah dengan resiliensi pada individu.

Berdasarkan hasil perhitungan di atas, hipotesis yang diajukan teruji, yaitu semakin positif dukungan para anggota komunitas maka semakin tinggi resiliensi pada ibu yang bergabung di persatuan orang tua yang memiliki anak down syndrome (POTADS) Bandung.

\section{SIMPULAN DAN SARAN}

\section{Kesimpulan}

1. Bahwa koefisien korelasi dukungan para anggota komunitas POTADS dengan resiliensi ibu menunjukkan bahwa terdapat hubungan positif dengan korelasi yang rendah antara dukungan para anggota komunitas dengan resiliensi pada ibu yang memiliki anak down syndrome di POTADS. Artinya bahwa semakin positif dukungan para anggota komunitas yang dirasakan oleh ibu maka semakin tinggi resiliensi.

2. Berdasarkan perhitungan statistik diperoleh bahwa pada aspek informational support merupakan aspek yang memiliki korelasi paling erat dengan resiliensi dibandingkan dengan aspek lainnya. Sehingga pada penelitian ini aspek informational support menjadi aspek yang paling terkait dengan tingginya resiliensi ibu. Ibu memaknakan bahwa ketika ibu sedang mengalami tekanan karena masalah anak, ibu mendapatkan saran, nasihat, arahan dan masukan dari para anggota komunitas sehingga ibu dapat memahami kondisi anaknya, permasalahan yang dialami ibu dapat terselesaikan dengan baik. ibu menjadi yakin bahwa ibu kuat dalam membesarkan anak down syndrome.

\section{Saran}

1. Bagi ibu dengan anak down syndrome disarankan untuk lebih meningkatkan lagi dalam mengikuti setiap kegiatan yang diadakan POTADS untuk menambah pengetahuan ibu mengenai bagaimana 
membesarkan anak down syndrome.

Diharapkan para ibu menjadi sering menghabiskan waktu bersama untuk berbagi pengalaman dan keluh kesah selama merawat anak karena dukungan dari sesama ibu yang memiliki anak down syndrome juga sangat ibu butuhkan karena hal itu dapat membantu ibu untuk meningkatan kualitas diri dan dapat menyesuaikan diri dengan berbagai rintangan yang dihadapi selama merawat anak down syndrome.

2. Bagi pihak komunitas persatuan orang tua anak dengan down syndrome atau disingkat POTADS diharapkan meningkatkan pemberian aspek dukungan informasi, dengan meningkatkan informasi yang ibu butuhkan seputar perawatan anak down syndrome dapat membuat ibu menjadi lebih memahami apa yang harus ibu lakukan pada anak down syndrome karena dukungan-dukungan seperti ini sangat dapat menambah tingginya resiliensi ibu sehingga ibu yang resiliensinya sudah tinggi dapat mempertahankan resiliensinya dan ibu yang resiliensinya rendah dapat meningkatkan resiliensinya.

\section{DAFTAR RUJUKAN}

Arikunto, S. (2010). Prosedur penelitian: suara pendekatan praktik (edisi revisi). Jakarta: Rineka Cipta.

Benard, B. (2004). Resiliency: What we have learned. San Fransisco: WestEd.

Barnett, W. S., \& Boyce, G. C. (1995). Effects of children with down syndrome on parents' activities. American Journal of Mental Retardation, 100, 115-127.

Fitri, I. (2017). Hubungan antara persepsi terhadap dukungan suami dengan psychological well being pada wanita penderita diabetes melitus tipe II usia dewasa madya di RSUD Al-Ihsan. (Skripsi diterbitkan). Bandung: Fakultas Psikologi Universitas Islam Bandung.

Lestari, K. (2007). Hubungan antara bentuk-bentuk dukungan sosial dengan tingkat resiliensi penyintas gempa di Desa Canan, Kecamatan Wedi, Kabupaten Klaten. (Skripsi). Semarang: Fakultas Psikologi Universitas Diponegoro.

Papalia, D. E., Old, S. W., \& Feldman, R. D. (2009). Perkembangan manusia edisi 10. Terjemahan oleh Brian Marswendy. Jakarta: Salemba Humanika.

Selikowitz, M. (2001). Mengenal sindroma down. Jakarta: Arcan.

Sarafino, E. P., \& Timothy, W. S. (2011). Healt psychology: Biopsychosocial interactions seventh edition. USA: Jhon Wiley \& Sons, Inc.

Shinta, E. (1995). Perilaku coping dan dukungan sosial pada pemuda penganggur, studi deskriptif terhadap pemuda penganggur di perkotaan. Jurnal Psikologi Indonesia, (1), 34-42 